\title{
Active response of soybean to defoliator Anticarsia gemmatalis Hübner: strategies to overcome protease inhibitor production
}

\author{
Respuesta activa de las plantas de soya contra el defoliador Anticarsia gemmatalis \\ Hübner: estrategias para sustituir la producción de inhibidores de las proteasas
}

\author{
Gilson Petrônio Paixão ${ }^{1}$, André Luiz Lourenção $o^{2}$, Camila Rocha Silva ${ }^{3}$, \\ Gláucia Cordeiro ${ }^{1}$, Rafael de Almeida Barros ${ }^{1}$, Joel Antônio Oliveira ${ }^{4}$, \\ Liliane Evangelista Visôtto ${ }^{3}$, Maria Goreti Almeida Oliveira ${ }^{1 *}$
}

\begin{abstract}
Endogenous mechanisms of plant resistance to herbivorous insects could be adapted to enable the development of alternative strategies for pest control. Activation of the lipoxygenase (LOX) pathway by jasmonic acid, the hormone responsible for activating genes encoding protease inhibitors (PI), is one of the main direct defenses of plants against insects. In this study, soybean cultivars at the V3 stage that were either susceptible or resistant to herbivorous insects were used to investigate changes in the activity of LOX and concentration of PIs in response to 24- or 48-h feeding by fourth and fifth instar Anticarsia gemmatalis (Lepidoptera: Noctuidae) larvae. LOX activity (0.0-0.007 nm s$/ 1 / \mathrm{mg}$ ) and the PI concentration (60 to $125 \mathrm{mg}$ of trypsin inhibitor / $\mathrm{mg}$ of protein and 90 to $120 \mathrm{mg}$ of trypsin inhibitor / $\mathrm{mg}$ protein after 24 and $48 \mathrm{~h}$ after attack, respectively) both increased in response to damage caused by A. gemmatalis. Proteolytic activity decreased by approximately $50 \%$ in cultivars with different degrees of resistance. Raised enzyme profiles in the midgut of A. gemmatalis may be related to tryptic enzymes that increased, compensating for the inhibition of proteases by entomotoxic substances of the soybean cultivars.
\end{abstract}

Key words: plant defense, lipoxygenases, velvet caterpillar.

\section{RESUMEN}

Los mecanismos de resistencia endógenos de las plantas contra insectos herbívoros pueden permitir el desarrollo de estrategias alternativas para el control de plagas. La activación de la vía de las lipoxigenasas con la producción de ácido jasmónico, hormona responsable por la activación de los genes inhibidores de proteasa, es una de las principales formas de defensa directa de las plantas contra los insectos. En el presente estudio, cultivares de soya en estadio V3, susceptibles y resistentes a insectos herbívoros fueron utilizadas para investigar las alteraciones en la actividad de LOX y la concentración de PIs, en respuesta al ataque de orugas en cuarto y quinto instar de Anticarsia gemmatalis (Lepidóptera: Noctuidae) por 24 y 48 horas. La actividad de LOX $\left(0,00\right.$ a 0,007 $\mathrm{nm} \mathrm{s}^{-1} / \mathrm{mg}$ ) y la concentración de inhibidores de proteasa (60 a $125 \mathrm{mg}$ de inhibidor de tripsina/ mg de proteína y 90 a 120 mg de inhibidor de tripsina/mg de proteína después de 24 y 48 horas del ataque respectivamente) aumenta en respuesta a los daños ocasionados por A. gemmatalis. La actividad proteolítica disminuyó aproximadamente en $50 \%$ en los cultivares con diferentes grados de resistencia. El aumento del perfil enzimático del intestino medio de A. gemmatalis puede estar relacionado al aumento de las enzimas trípticas para compensar la inhibición de proteasas por sustancias entomotóxicas de los cultivares de soya.

Palabras clave: defensa de plantas, lipoxigenasas, oruga-de-soja.

\section{Introduction}

Pests can significantly limit the productive potential of soybean throughout its life cycle. Anticarsia gemmatalis Hübner, 1818 larva (Lepidoptera: Noctuidae), one of the main pests of soybean, can consume $90 \mathrm{~cm}^{2}$ of leaves, equivalent to 2.1 times their weight, every $24 \mathrm{~h}$ during the larval period (Miklos et al., 2007).

Host plant resistance is compatible with other methods of pest management, because it can impact the biology and/or behavior of herbivorous insects

\footnotetext{
Federal University of Viçosa, Institute of Biotechnology Applied to Agriculture-BIOAGRO, Viçosa, Brazil. Institute Campinas Agronomic, Campinas, Brazil.

Federal University of Viçosa, Campus Rio Paranaíba, Rio Paranaíba, Brazil.

4 Federal University of Viçosa, Departament of Chemistry, Viçosa, Brazil.

* Corresponding Author: malmeida@ufv.br
}

Fecha de Recepción: 1 Junio, 2015.

Fecha de Aceptación: 21 Enero, 2016. 
negatively (Dunse et al., 2010a). However, these insects can evolve defense strategies to use or metabolize the toxic substances produced by the plants. This coevolution biochemistry shows how a toxic plant can defend itself and how phytophagous insects can overcome these defenses by detoxifying or sequestering the plant toxins (Michereff et al., 2014). Using cultivars with a moderate level of resistance to herbivores and that have a positive effect on natural enemy attraction, it would be possible to keep pests at low infestation levels without causing economic damage to the producer, thus contributing to the ecological sustainability of agricultural systems (Michereff et al., 2014).

Endogenous mechanisms of plant resistance to insect herbivores are alternative strategies for controlling pests (Dunse et al., 2010b; Scott et al., 2010). The production of jasmonic acid in the lipoxygenase (LOX) pathway can activate genes encoding protease inhibitors (PI), which is a direct defense mechanism of plants against herbivorous insects (Farmer \& Ryan 1992; Shivaji et al., 2012). PI are promising for plant defense, because when ingested they block digestive proteases in the insect intestine. This limits the release of amino acids from the diet and affects the synthesis of proteins required for insect growth, development and reproduction (Zhu-Salzman \& Zeng 2008).

The aim of this study was to determine the biochemical aspects and development of $A$. gemmatalis and the physiological responses to five soybean cultivars with different degrees of resistance to insects.

\section{Materials and Methods}

The experiments were performed in the Laboratory of Enzymology, Biochemistry of Proteins and Peptides of the Institute of Biotechnology Applied to Agriculture (BIOAGRO) and in the Entomology Laboratory (LCI) of the Department of Biochemistry and Molecular Biology (DBB) of the Federal University of Viçosa (UFV) in Viçosa, Minas Gerais, Brazil.

\section{Rearing the insects}

Eggs of A. gemmatalis were obtained from the National Research Center of Soybean (CNPSo) in Londrina, Paraná State, Brazil and kept in the LCI of the $\mathrm{DBB} / \mathrm{UFV}$ at $25 \pm 2{ }^{\circ} \mathrm{C}$ and $70 \pm 10 \%$ relative humidity
(RH). Larvae A. gemmatalis were kept in an incubator at $25^{\circ} \mathrm{C}, 60 \pm 10 \% \mathrm{RH}$ and a 14-h photoperiod, and fed an artificial diet (Hoffman et al., 1985).

\section{Soybean seedlings}

Seeds of soybean cultivars [Glycine $\max (\mathrm{L}$. Merrill] were obtained from the Agronomic Institute of Campinas (IAC) of São Paulo State, Brazil. The soybean varieties used were as follows: IAC-PL1, which is susceptible to insects, and IAC-17, IAC18, IAC-19 and IAC-24, which show different levels of resistance to insects (Lourenção et al., 1997). Seedlings were grown in 4.0-kg pots with soil to the V3 stage, with no foliar application of any product, and with three soybean plants per greenhouse. The first three trifoliate leaves of each plant were collected, frozen in liquid nitrogen and stored at $-80{ }^{\circ} \mathrm{C}$ until they were used to evaluate LOX activity and PI production.

\section{Damage by A. gemmatalis larvae}

The V3-stage soybean plants were subjected to damage by fourth- and/or fifth-instar A. gemmatalis larvae. One larva was placed on the first trifoliate of each plant. After $24 \mathrm{~h}$ and $48 \mathrm{~h}$, the three leaflets of the first trifoliated leaf were collected, frozen in liquid nitrogen and stored at $-80^{\circ} \mathrm{C}$ for use in obtaining the plant extracts. Larvae were then taken off the plants and their midguts removed for enzymatic analysis.

\section{Enzyme extracts of the larva midgut}

The midguts of A. gemmatalis larvae were extracted after being dissected and placed in $\mathrm{HCl}$ $10^{-3} \mathrm{M}$ at $4{ }^{\circ} \mathrm{C}$ in $2 \mathrm{~mL}$ plastic tubes. The enzyme extract was obtained by cell disruption during nine cycles of freezing in liquid nitrogen and thawing in a water bath at $37^{\circ} \mathrm{C}$. After the cycles, fractions of $1 \mathrm{~mL}$ of the extract were centrifuged in $2 \mathrm{~mL}$ plastic tubes with caps at 100,000 $\mathrm{g}$ for $30 \mathrm{~min}$ at $4{ }^{\circ} \mathrm{C}$. The supernatant containing soluble material was removed and kept at $-18{ }^{\circ} \mathrm{C}$ until the protein concentration and enzymatic activity was determined.

\section{Determination of protein concentration}

The protein concentration of the enzyme extract of A. gemmatalis was obtained (Bradford, 1976), 
using bovine serum albumin (BSA) $0.2 \mathrm{mg} / \mathrm{mL}$ as standard.

\section{Protease activity in the $A$. gemmatalis midgut}

Protease activity was determined using the substrate azocasein $2 \%(\mathrm{w} / \mathrm{v}$ ) in Tris- $\mathrm{HCl} 0.1 \mathrm{M} \mathrm{pH}$ 8.0 (Tomarelli et al., 1949) in a reaction mixture of $50 \mu \mathrm{L}$ substrate and $60 \mu \mathrm{L}$ enzyme extract, which was then incubated for $30 \mathrm{~min}$ at $37^{\circ} \mathrm{C}$. The reaction was stopped by adding $240 \mu \mathrm{L}$ trichloroacetic acid $10 \%(w / v)$. The samples were then homogenized by vortexing and maintained at rest on ice for $15 \mathrm{~min}$, followed by centrifugation at $8000 \mathrm{~g}$ for $5 \mathrm{~min}$ at $25^{\circ} \mathrm{C}$ to remove the precipitated protein. An aliquot of $240 \mu \mathrm{L}$ of supernatant was transferred to tubes containing $280 \mu \mathrm{L} \mathrm{NaOH} 1 \mathrm{M}$. Protease activity was monitored in a spectrophotometer at $440 \mathrm{~nm}$. The experiment was conducted in triplicate.

\section{Amidase and Esterase activity in the A. gemmatalis midgut}

Amidase activity was evaluated using the chromogenic substrate $\mathrm{N}$ - $\alpha$-benzoyl-L-arginine 4-nitroanilide hydrochloride (L-BApNA) at a final concentration of $1.2 \mathrm{mM}$ at $25^{\circ} \mathrm{C}$ in Tris- $\mathrm{HCl} 0.1$ $\mathrm{M} \mathrm{pH} 8.2$ containing $20 \mathrm{mM} \mathrm{CaCl}_{2}$ (Erlanger et al., 1961). The reaction mixture comprised $0.5 \mathrm{~mL}$ substrate, $0.5 \mathrm{~mL}$ buffer and $10 \mu \mathrm{L}$ enzyme extract. Initial rates of trypsin-like serine proteases were determined by the formation of $p$-nitroanilide by measuring the absorbance increase at $410 \mathrm{~nm}$ over $2.5 \mathrm{~min}$, using a molar extinction coefficient of 8800 $\mathrm{M}^{-1} \cdot \mathrm{cm}^{-1}$ for the calculations. The experiments were performed in triplicate.

Esterase activity was assessed using the substrate $\mathrm{N}$ - $\alpha$ - $p$-tosyl-L-arginine methyl ester (L-TAME) at a final concentration of $0.1 \mathrm{mM}$ at $25^{\circ} \mathrm{C}$ in Tris- $\mathrm{HCl}$ $0.1 \mathrm{M} \mathrm{pH} 8$ containing $20 \mathrm{mM} \mathrm{CaCl}_{2}$ (Hummel, 1959). Initial rates of trypsin-like serine proteases were determined by measuring the absorbance at $247 \mathrm{~nm}$ over $2.5 \mathrm{~min}$ using a molar extinction coefficient of $540 \mathrm{M}^{-1} \cdot \mathrm{cm}^{-1}$ for the calculations. The experiment was conducted in triplicate.

\section{Cysteine protease activity in the A. gemmatalis midgut}

The activity of cysteine proteases was determined by adapting the method of Erlanger et al. (1961)
(Mendonça et al., 2012). The reaction mixture included $0.5 \mathrm{~mL}$ Tris- $\mathrm{HCl} 0.1 \mathrm{M}$ pH 8.0, $1 \mathrm{mM}$ dithiothreitol, $10 \mu \mathrm{L}$ enzyme extract and $0.1 \mathrm{~mL}$ of a $10 \mathrm{mM}$ benzamidine inhibitor, which was then incubated for $15 \mathrm{~min}$ at room temperature. To the mixture was added $0.5 \mathrm{~mL}$ L-BApNA to a final concentration of $1.2 \mathrm{mM}$. Initial rates of cysteine proteases were determined by measuring the absorbance at $410 \mathrm{~nm}$ versus time $(2.5 \mathrm{~min})$ using a molar extinction coefficient of $8800 \mathrm{M}^{-1}$. $\mathrm{cm}^{-1}$ for the calculations. The experiment was conducted in triplicate.

\section{Leaf extract}

Crude leaf extract was prepared at $4{ }^{\circ} \mathrm{C}$ by weighing soybean leaves, which were then immediately frozen in liquid nitrogen and crushed in a mortar. The powder obtained was homogenized in a $50 \mathrm{mM}$ sodium phosphate buffer, $\mathrm{pH} 6.5$ at a ratio of 1:3 (w/v) and centrifuged at 17,200 $g$ for $60 \mathrm{~min}$ at $4{ }^{\circ} \mathrm{C}$, following modifications of the methodology of Batista et al. (2002). The total protein concentration, LOX activity and the concentration of PI were determined in the supernatant, named the 'crude extract'.

\section{LOX activity}

The activity of LOX on linoleic acid was determined in a stock solution of $10 \mathrm{mM}$ sodium linoleate containing $1.0 \mu \mathrm{L}$ crude leaf extract and $4.0 \mu \mathrm{L}$ of a stock solution of sodium linoleate in $1.0 \mathrm{~mL}$ sodium phosphate buffer $50 \mathrm{mM}, \mathrm{pH} 6.5$. This activity was measured by forming a system of conjugated double bonds in the hydrogen peroxide, increasing absorbance at $234 \mathrm{~nm}$ (Axelrod et al., 1981). Initial rates were determined by measuring the absorbance at $234 \mathrm{~nm}$ versus time $(2.5 \mathrm{~min})$, using a molar extinction coefficient of $25,000 \mathrm{M}^{-1}$. $\mathrm{cm}^{-1}$ for the calculations. The experiment was conducted in triplicate.

\section{Determination of protease inhibition}

PI in leaf crude extract were determined using bovine trypsin (Kakade et al., 1974). The trypsin activity in the presence of inhibitors was determined using $50 \mu \mathrm{L}$ leaf extract, $500 \mu \mathrm{L}$ Tris- $\mathrm{HCl} 0.1 \mathrm{M} \mathrm{pH}$ 8.2 , with $20 \mathrm{mM} \mathrm{CaCl}_{2}$ and $50 \mu \mathrm{L}$ trypsin solution $4.7 \times 10^{-5} \mathrm{M}$ in a test tube. The control treatment was 
performed using $550 \mu \mathrm{L} 0.1 \mathrm{M}$ Tris-HCl, $\mathrm{pH} 8.2$, with $20 \mathrm{mM} \mathrm{CaCl}_{2}$ and $50 \mu \mathrm{L}$ trypsin solution 4.7 $\times 10^{-5} \mathrm{M}$. The test tubes were incubated for $5 \mathrm{~min}$ at $25^{\circ} \mathrm{C}$. From each tube, $500 \mu \mathrm{L}$ of the incubation mixture was removed and added to another tube containing $500 \mu \mathrm{L} 0.1 \mathrm{M}$ Tris-HCl, $\mathrm{pH}$ 8.2, with $20 \mathrm{mM} \mathrm{CaCl}_{2}$ and $500 \mu \mathrm{L} 1.2 \mathrm{mM} \mathrm{L}-\mathrm{BApNA}$. The absorbance of each solution was determined at 410 $\mathrm{nm}$ for $2.5 \mathrm{~min}$. The experiment was performed in triplicate. The results were converted to mg trypsin inhibited per gram of protein according to

Equation 1: $\mathrm{mg}$ trypsin inhibited/gram of protein $=\mathrm{A} \times \mathrm{B} /(\mathrm{C} \times 1.000 \times \mathrm{P})$,

where $\mathrm{A}$ is the absorbance at $410 \mathrm{~nm}$ of the control-410 $\mathrm{nm}$ absorbance of the sample, $\mathrm{B}$ is sample dilution, $\mathrm{P}$ is the concentration in $\mathrm{g} / \mathrm{mL}$ of protein extracts, and $\mathrm{C}$ is 0.019 (trypsin factor; i.e. the product of the action of $1 \mu \mathrm{g}$ of active trypsin on L-BAPNA results in an absorbance reading of 0.019 at $410 \mathrm{~nm}$ ).

\section{Statistical analyses}

Data relating to proteolytic and trypsin-like amidase activities were combined for analysis. Data were subjected to analysis of normality and variance with the R Program at a reliability level of $95 \%$.

\section{Results}

The activity of LOX (Figure 1) after $48 \mathrm{~h}$ of feeding by $A$. gemmatalis, increased significantly

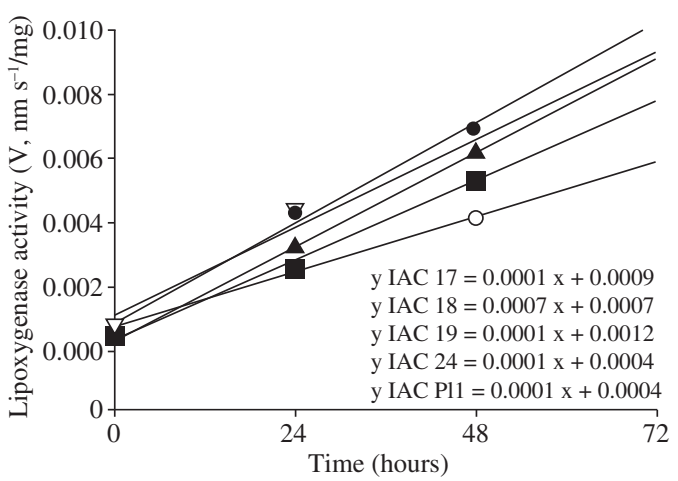

- IAC 17 O IAC $18 \Delta$ IAC $19 \nabla$ IAC $24 \square$ IAC PL1

Figure 1. Lipoxygenase activity in leaf extracts of soybean cultivars with different degrees of resistance when damaged by Anticarsia gemmatalis (Lepidoptera: Noctuidae). Plant*time*cultivars interactions were not significant $\left(\mathrm{gl}_{\text {erro }}=44, \mathrm{~F}=6.01, \mathrm{P}>0.05\right)$. with cultivar type $(\mathrm{P}=0.0189)$, time $(\mathrm{P}<0.0001)$ and with the cultivar $\times$ time interaction $(\mathrm{P}=0.0174)$. LOX showed no activity at time zero (beginning of the attack) in resistant (IAC-17, IAC-18, IAC-19 and IAC-24) and susceptible (IAC-PL-1) cultivars to A. gemmatalis. IAC-18, which is moderately resistant to A. gemmatalis, presented a lower rise in lipoxygenase activity when compared the other.

The production of PI during the $48 \mathrm{~h}$ period increased in all cultivars after larval damage (Figure 2), but without interactions of cultivar parameters or cultivar $\mathrm{x}$ time interaction $(\mathrm{P}=0.0561$ and $\mathrm{P}=0.5481$, respectively), differing from that observed for the time parameter $(\mathrm{P}=0.0001)$.

Proteolytic activity in the midgut of larvae A. gemmatalis decreased with time after feeding (Table 1). Activity showed a greater reduction in IAC-19 $(\mathrm{P}<0.05)$, which has standard resistance to insects, compared with the more resistant (IAC-17,

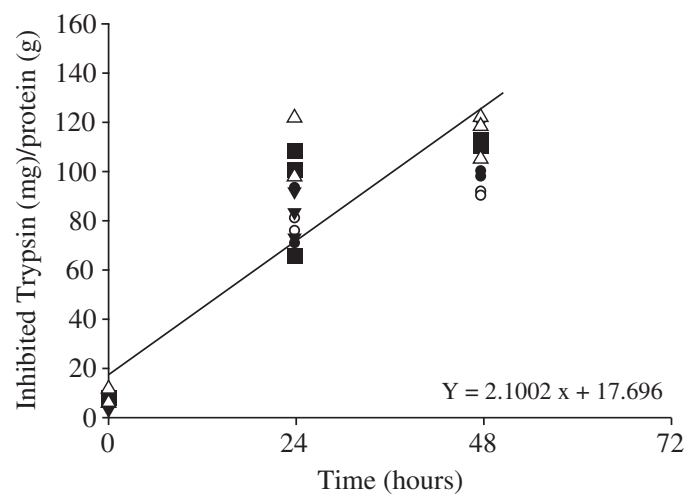

Figure 2. Inhibited trypsin activity with inhibitor from soybean cultivars with different degrees of resistance to insects. Caterpillar*time interaction was not significant (glerro $=44$, $\mathrm{F}=213.42, \mathrm{P}>0.05$ ).

Table 1. Proteolytic enzyme extract from the midgut of velvet bean caterpillar Anticarsia gemmatalis (Lepidoptera: Noctuidae) larvae fed soybean cultivars with different degrees of resistance to insects.

\begin{tabular}{|c|c|c|}
\hline \multirow{2}{*}{ Cultivars } & \multicolumn{2}{|c|}{$\begin{array}{c}\text { Activity Proteolytic } \\
\text { (Abs } 440 \mathrm{~nm} / \text { protein } \mathrm{mg} \text { ) }\end{array}$} \\
\hline & 24 hours & 48 hours \\
\hline IAC PL-1 & $0.047 \pm 0.004 \mathrm{Aa}$ & $0.045 \pm 0.017 \mathrm{Aa}$ \\
\hline IAC 17 & $0.072 \pm 0.011 \mathrm{Aa}$ & $0.062 \pm 0.005 \mathrm{Aa}$ \\
\hline IAC 18 & $0.067 \pm 0.006 \mathrm{Aa}$ & $0.041 \pm 0.012 \mathrm{Aa}$ \\
\hline IAC 19 & $0.136 \pm 0.021 \mathrm{Ba}$ & $0.069 \pm 0.015 \mathrm{Ab}$ \\
\hline IAC 24 & $0.056 \pm 0.022 \mathrm{Aa}$ & $0.054 \pm 0.017 \mathrm{Aa}$ \\
\hline
\end{tabular}


IAC-18 and IAC-24) and the susceptible IAC-PL-1 cultivars.

The same capital letters show no difference at $5 \%$ probability by Tukey's test between differents cultivars (column). The same lowercase letters show no difference at $5 \%$ probability by Tukey's test in differents times in the same cultivar (line).

Amidase activity of trypsin-like did not differ with the type of cultivar $(\mathrm{P}>0.05)$, time $(\mathrm{P}>0.05)$ and cultivar $\times$ time interaction $(\mathrm{P}>0.05)$, according to data presented in the table 2. Esterase activity of trypsin-like varied over time $(\mathrm{P}<0.05)$, but without an interaction with time $(\mathrm{P}>0.05)$, significantly increased within 48 hours, except for the larvae subjected to treatment with cultivar IAC 17 (Table 2).

The same capital letters show no difference at $5 \%$ probability by Tukey's test between different cultivars (column). The same lowercase letters show no difference at $5 \%$ probability by Tukey's test in differents times in the same cultivar (line).

The activity of cysteine proteases in the gut of larval A. gemmatalis was similar across the five cultivars over the different feeding times $(\mathrm{P}>0.05)$ (Table 3).

The same capital letters show no difference at $5 \%$ probability by Tukey's test between different cultivars (column). The same lowercase letters show no difference at $5 \%$ probability by Tukey's test in different times in the same cultivar (line).

Table 2. Amidase and esterase activity of trypsin-like enzyme extract from the midgut of velvet bean caterpillar Anticarsia gemmatalis (Lepidoptera: Noctuidae) when fed soybean cultivars with different degrees of resistance to insects.

\begin{tabular}{|c|c|c|}
\hline \multirow[b]{2}{*}{ Cultivars } & \multicolumn{2}{|c|}{$\begin{array}{l}\text { Trypsin-like Amidase Activity } \\
\left(\mathrm{V}, \mu \mathrm{M} \cdot \mathrm{s}^{-1} / \text { protein } \mathrm{mg}\right)\end{array}$} \\
\hline & 24 hours & 48 hours \\
\hline IAC PL-1 & $0.003 \pm 0.001 \mathrm{Aa}$ & $0.005 \pm 0.003 \mathrm{Aa}$ \\
\hline IAC 17 & $0.013 \pm 0.003 \mathrm{Aa}$ & $0.016 \pm 0.010 \mathrm{Aa}$ \\
\hline IAC 18 & $0.019 \pm 0.001 \mathrm{Aa}$ & $0.002 \pm 0,000 \mathrm{Aa}$ \\
\hline IAC 19 & $0.011 \pm 0.010 \mathrm{Aa}$ & $0.009 \pm 0.007 \mathrm{Aa}$ \\
\hline \multirow[t]{2}{*}{ IAC 24} & $0.006 \pm 0.001 \mathrm{Aa}$ & $0.005 \pm 0.002 \mathrm{Aa}$ \\
\hline & \multicolumn{2}{|c|}{$\begin{array}{l}\text { Trypsin-like Esterase Activity } \\
\left(\mathrm{V}, \mu \mathrm{M} \cdot \mathrm{s}^{-1} / \text { protein } \mathrm{mg}\right)\end{array}$} \\
\hline Cultivars & 24 hours & 48 hours \\
\hline IAC PL-1 & $0.105 \pm 0.003 \mathrm{Aa}$ & $1.715 \pm 1.610 \mathrm{Ab}$ \\
\hline IAC 17 & $0.189 \pm 0,016$ Aa & $0,059 \pm 0,039 \mathrm{Ab}$ \\
\hline IAC 18 & $0.308 \pm 0,277 \mathrm{Aa}$ & $1.717 \pm 1.393 \mathrm{Ab}$ \\
\hline IAC 19 & $0.333 \pm 0.206 \mathrm{Aa}$ & $1.551 \pm 0.523 \mathrm{Ab}$ \\
\hline IAC 24 & $0.060 \pm 0.011 \mathrm{Aa}$ & $0.411 \pm 0,015 \mathrm{Ab}$ \\
\hline
\end{tabular}

Table 3. Cysteine protease activity of the enzyme extract from midgut of velvet bean caterpillar Anticarsia gemmatalis (Lepidoptera: Noctuidae) fed soybean cultivars with different degrees of resistance to insects.

\begin{tabular}{lcc}
\hline & \multicolumn{2}{c}{$\begin{array}{c}\text { Cysteine protease Activity } \\
\left(\mathrm{V}, \mu \mathrm{M} \cdot \mathrm{s}^{-1} / \text { protein } \mathrm{mg}\right)\end{array}$} \\
\hline Cultivars & 24 hours & 48 hours \\
\hline IAC PL-1 & $0.002 \pm 0.0003 \mathrm{Aa}$ & $0.002 \pm 0.0001 \mathrm{Aa}$ \\
IAC 17 & $0.002 \pm 0.0002 \mathrm{Aa}$ & $0.002 \pm 0.0001 \mathrm{Aa}$ \\
IAC 18 & $0.006 \pm 0.0003 \mathrm{Aa}$ & $0.005 \pm 0.0003 \mathrm{Aa}$ \\
IAC 19 & $0.006 \pm 0.0002 \mathrm{Aa}$ & $0.002 \pm 0.0001 \mathrm{Aa}$ \\
IAC 24 & $0.004 \pm 0.0002 \mathrm{Aa}$ & $0.001 \pm 0.0005 \mathrm{Aa}$ \\
\hline
\end{tabular}

\section{Discussion}

The biological and biochemical responses of A. gemmatalis larvae fed susceptible or resistant soybean showed that antimetabolic agents (i.e. those that increase LOX and the PI) produced by this plant can cause physiological changes in the ability of A. gemmatalis larvae to digest proteins. However, this insect can adapt to these compounds through the hyperproduction either of enzymes sensitive to these plant inhibitors or of insensitive enzymes, as well as other classes of protease (Marinho et al., 2010; Moreira et al., 2011).

The highly specific activity of LOX after injury results from the increased content of PI through activation of the LOX pathway as a plant defense mechanism. Induction of LOX activity was also recorded in passion fruit leaves damaged by the oligophagous Agraulis vanillae vanillae (Linnaeus, 1758) (Lepidoptera: Nymphalidae) and the generalist Spodoptera frugiperda (JE Smith, 1797) (Lepidoptera: Noctuidae). The interaction between soybean and A. gemmatalis through induction of the LOX pathway enhances the activity of these enzymes and the final products of the route, the PI.

The increase of PI in soybean is the result of a response to the increased activity of LOX, characterizing this defense pathway. Herbivory increased the concentration of PI in leaves of soybean cultivars after $48 \mathrm{~h}$ of damage by increasing the activity of LOX. Plants increase the activity of inhibitors in their tissues and the production of active broad-spectrum inhibitors as a defense against insect pests (Tiffin \& Gaut, 2011). In addition, they produce highly specific inhibitors, resistant to proteolysis and active under the variable $\mathrm{pH}$ conditions of the insect midgut (Christeller, 2005). Inhibitors induced 
by plant damage are used as a model system to study plant defense mechanisms (Farmer \& Ryan, 1992; Shivaji et al., 2012; Siqueira-Júnior et al., 2008). After $24 \mathrm{~h}$ and $48 \mathrm{~h}$ of treatment with methyl jasmonate, mechanical wounding or herbivory, passion fruit leaves showed higher accumulation of PI, demonstrated by increased inhibition of trypsin (Siqueira-Júnior et al., 2008).

The highest impact on the activity of proteolytic enzymes in the gut of A. gemmatalis fed IAC-19 compared to those fed IAC-17, IAC-18 or IAC-24, suggests that the first cultivar produces more potent and/or multidomain PI against herbivores. The lower proteolytic activity in the standard susceptible cultivar IAC-PL-1 suggests the presence of a PI with a high inhibition constant that reduces the activity of proteolytic enzymes in the gut of A. gemmatalis larvae (Lourenção et al., 1997).

The increase in amidase and esterase activity over time in the gut of $A$. gemmatalis larvae fed IAC-19 and in esterase activity in those fed IAC-17, IAC-18 and IAC-24 could be related to increased production of trypsin-like enzymes that offset proteases inhibited by entomotoxic substances in these cultivars. This induces insects to use available amino acids to synthesize more protease rather than for the production of proteins for growth and development (Broadway, 1995). Similarly, the sudden decrease in amidase activity in the gut of larvae fed the cultivars IAC-17 and IAC-18 reinforces a possible inhibitory effect of the PI.

The expression of cysteine proteases in the midgut of A. gemmatalis larvae could avoid a host defense that is rich in serine protease inhibitors. The presence of cysteine proteases in the midgut (e.g. digestive enzymes) is an adaption to ingest food rich in serine protease inhibitors (Mendonça et al., 2012). The increased activity of cysteine proteases in the gut of larvae fed on the five soybean cultivars confirms the presence of this adaptive mechanism in A. gemmatalis. Although plants have defense mechanisms, insects may metabolize and use such toxic substances to protect themselves against their own natural enemies (Michereff et al. 2014).

The changes in soybean biochemistry caused by A. gemmatalis larvae serve as a model to produce cultivars that are resistant to this pest. The plant responds to insect damage by activating biochemical defense pathways. In response, the insect adapts its digestive enzymes to maintain proteolysis, which is the major amino acid source in phytophagous insects. This ensures a supply of amino acids for biosynthesis in diets low in nitrogen (Bown et al., 2004). Knowledge of the digestive enzymes of $A$. gemmatalis larvae is essential to develop strategies to control this important insect pest.

\section{Acknowledgements}

This study was supported by grants of the "Conselho Nacional de Desenvolvimento Científico e Tecnológico (CNPq)", "Coordenação de Aperfeiçoamento de Pessoal de Nível Superior (CAPES)", "Fundação de Amparo à Pesquisa do Estado de Minas Gerais (FAPEMIG)" and "Instituto Nacional de Ciência e Tecnologia em Interações Planta-Praga (INCT-IPP)", Brazil.

Asia Science edited and corrected the English of this manuscript.

\section{Literature Cited}

Axelrod, B.; Cheesbrough, T.M.; Laakso, S.

1981. Lipoxygenases from soybeans. Methods in Enzymology. 71, 441-451.

Batista, R.B.; Oliveira, M.G.A.; Pires, C.V.; Piovesan, N.D.;

Rezende, S.T.; Moreira, M.A.

2002. Caracterização bioquímica e cinética de lipoxigenases de plantas de soja submetidas à aplicação de ácidos graxos poliinsaturados. Pesquisa Agropecuária Brasileira. 37 (11), 1517-1524.

Bown, D.P.; Wilkinson, H.S.; Jongsma, M.A.; Gatehouse, J.A. 2004. Characterization of cysteine proteinases responsible for digestive proteolysis in guts of larval western corn rootworm (Diabrotica virgifera) by expression in the yeast Pichia pastoris. Insect Biochemistry and Molecular Biology. 34 (4), 305-320.
Bradford, M.M.

1976. A rapid and sensitive method for the quantification of microgram quantities of proteins utilizing the principle of protein dye binding. Analytical Biochemistry 72, 248-254.

Broadway, R.M.

1995. Are insects resistant to plant proteinase inhibitors? Journal of Insect and Physiology. 41 (2), 107-116.

Christeller, J.T.

2005. Evolutionary mechanisms acting on proteinase inhibitor variability. FEBS Journal. 272 (22), 5710-5722.

Dunse, K.M.; Stevens, J.A.; Lay, F.T.; Gaspar, Y.M.; Heath, R.L.; Anderson, M.A.

2010a. Coexpression of potato type I and II proteinase inhibitors gives cotton plants protection against insect damage in the field. Proceedings of the National Academy of Sciences of 
the United States of America-Physical Sciences. 107 (34), 15011-15015.

Dunse, K.M.; Kaas, Q.; Guarino, R.F.; Barton, P.A.; Craik, D.J.; Anderson, M.A.

2010b. Molecular basis for the resistance of an insect chymotrypsin to a potato type II proteinase inhibitor. Proceedings of the National Academy of Sciences of the United States of America-Physical Sciences. 107 (34), 15016-15021.

Erlanger, B.F.; Kokowsky, N.; Cohen, W.

1961. The preparation and properties of two new chromogenic substrates of trypsin. Archives of Biochemistry and Biophysic. 95 (2), 271-278.

Farmer, E.E.; Ryan, C.A. 1992. Octadecanoid precursors of jasmonic acid activate the syntesis of wound-inducible proteinase inhibitors. Plant Cell. 4 (2), 129-134.

Hoffman-Campo, C.B.; Oliveira, E.B.; Moscardi, F.

1985. Criação masal da lagarta da soja (Anticarsia gemmatalis) Londrina, Embraba-CMPSo. 23 p.

Hummel, B.C.W.

1959. A modified spectrophotometric determination of chymotrypsin, trypsin and thrombin. Canadian Journal Biochemistry and Physiology. 37: 1393-1399.

Kakade, M.L.; Rackis, J.J.; McGhee, J.E.

1974. Determination of trypsin inhibitor activity of soy products: a collaborative analysis of an improved procedure. Cereal Chemistry Journal. 51, 376-382.

Lourenção, A.L.; Miranda, M.A.C.; Pereira, J.C.V.N.A.; Ambrosano, G.M.B.

1997. Resistência de soja a insetos: Comportamento de cultivares e linhagens em relação a percevejos e desfolhadores. Anais da Sociedade Entomológica do Brasil. 26 (3), 543-550.

Marinho, J.S.; Oliveira, M.G.A.; Guedes, R.N.C.; Pallini, A.; Oliveira, J.A.

2010. Biochemical response of Thyrinteina leucoceraea to proteases inhibitor in guava plants. IDESIA, 28 (3): 101-109.

Mendonça, E.G.; Oliveira, M.G.A.; Visôtto, L.E.; Guedes, R.N.C. 2012. Midgut cysteine-proteinase activity in the velvetbean caterpillar (Anticarsia gemmatalis (Hübner)). Journal of Pest Science. 85 (1), 117-123.

Michereff, M.F.F.; Michereff Filho, M.; Blassioli-Moraes, M.C.; Laumann, R.A.; Diniz, I.R.; Borges, M.

2014. Effect of resistant and susceptible soybean cultivars on the attraction of egg parasitoids under field conditions. Journal of Applied Entomology. doi: 10.1111/ jen.12148.

Miklos, J.A.; Paradise, M.S.; Toedebusch, A.S.; Viegas, A. 2007. Laboratory and field evaluations of transgenic soybean exhibiting high-dose expression of a synthetic Bacillus thuringiensis cry1A gene for control of Lepidoptera. Journal of Economic Entomology. 98 (2), 577-587.

Moreira, L.F.; Campos, W.G.; Ribeiro, F.R.; Guedes, R.N.C.; Oliveira, M.G.A.

2011. Survival and developmental impairment induced by the trypsin inhibitor bis-benzamidine in the velvetbean caterpillar (Anticarsia gemmatalis). Crop Protection. 30 (10), 1285-1290.

Scott, I.M.; Thaler, J.S.; Scott, J.G.;

2010. Response of a generalist herbivore Trichoplusia ni to jasmonate-mediated induced defense in tomato. Journal of Chemical Ecology. 36 (5), 490-499.

Shivaji, R.; Camas, A.; Ankala, A.; Engelberth, J.; Tumlinson, J.H.; Williams, W.P.; Wilkinson, J.R.; Luthe, D.S.

2012. Plants on constant alert: elevated levels of jasmonic acid and jasmonate-induced transcripts in caterpillarresistant maize. Journal of Chemical Ecology. 36 (2), 179-191.

Siqueira-Júnior, C.L.; Jardim, B.C.; Urményi, T.P.; Vicente, A.C.; Hansen, E.; Otsuki, K.; da Cunha, M.; Madureira, H.C.; de Carvalho, D.R.; Jacinto, T.

2008. Wound response in passion fruit (Passiflora f. edulis flavicarpa) plants: gene characterization of a novel chloroplasttargeted allene oxide synthase up-regulated by mechanical injury and methyl jasmonate. Plant Cell Reports. 27 (2), 387-397.

Tiffin, P.; Gaut, B.S.

2011. Molecular evolution of the wound-induced serine protease inhibitor wip 1 in zea and related genera. Molecular Biology and Evolution. 18 (11), 2092-2101.

Tomarelli, R.M.; Charney, J.; Harding, M.L.

1949. The use of azoalbumin as a substrate in the colorimetric determination or peptic and tryptic activity. Journal of Laboratory and Clinical Medicine. 34 (3), 428-433.

Zhu-Salzman, K.; Zeng, R.S.

2008. Molecular mechanisms of insect adaptation to plant defense: Lessons learned from a Bruchid beetle Keyan. Journal of Insect Science. 15, 477-481. 
